\title{
Work-Integrated Teaching Mode Based on An E-learning Platform
}

\author{
Lina $\mathrm{Yu}$ \\ Jiangxi Science and Technology Normal University, Nanchang, China
}

\begin{abstract}
In work-integrated learning, students leave teachers to practice on work placement, but the teachers can still use e-learning to monitor student through an e-learning platform and it allows students to actively learn the theoretical knowledge. Work-integrated e-learning (WIEL) is a new research field, focusing on learning processes concerning both employees and organizations, using e-learning as a way of gaining new knowledge relevant for the work process. Learning at work is more multidimensional learning compared to educational institutions.
\end{abstract}

Index Terms: Work-integrated E-learning (WIEL); teaching platform; simulation teaching; course packages

(C) 2011 Published by MECS Publisher. Selection and/or peer review under responsibility of the International Conference on E-Business System and Education Technology

\section{Introduction}

This paper introduces the construction of an e-learning teaching platform and how to implement teaching through e-learning teaching platform by describing the function of e-learning teaching platform. Solving the problem that students who are separated from their teachers can continue to study is most likely to the guarantee the success of the reform of work-integrated teaching mode.

Through work-integrated learning, students leave the school and move into society. They can be part of the actual production. There are more opportunities to help students understand the production process and production positions. Working in the real positions can practice their abilities. Although students work in work placement, teachers also need teach them professional knowledge; this is work-integrated teaching mode. However, there are many problems in work-integrated teaching mode: How students can be instructed by teachers in learning? How do students learn? How do students use the network for better learning? These are new topics.

From the beginning of this century, mankind has really entered the information age. Learning characteristics of information age reflect in the three areas: the networking of learning environment, digitization of learning resources and learning diversity. As the development of network technology, network-teaching platform as a tool of education has been growing more and more important for teachers and almost everyone is involved in it [1]. The establishment of web-based e-learning teaching platform will make students in different practice sites

* Corresponding author.

E-mail address: angelfish1108@163.com 
improve their learning efficiency through e-learning teaching. This is also a new and effective teaching method for students to achieve knowledge acquisition and enhance their practical ability.

This paper will focus on:

- Analyzing the function of an e-learning teaching platform

- Formulating an e-learning teaching platform model which adapts to work-integrated teaching mode.

- Describe the design of e-learning teaching platform model and critique its use.

\section{Status Quo of E-learning and Simulation Teaching}

The term 'e-learning' is used in a variety of ways by different literature. Allan [2] defined "E-learning involves learning that is delivered, enabled or mediated by electronic technology, for the explicit purposes of training and/ or education." Clark \& Mayer [3] concluded "e-learning courses include both content (that is, information) and instructional methods (that is, technique) that help people learn the content."

Some scholars put forward some potential disadvantages which exist in e-learning teaching.

Firstly, it is difficult to control during implementation. E-learning gives students more initiative, however, how can teachers ensure the quality of student learning? [4] How can remote supervisors monitor students' learning? Web contains a plethora of unauthenticated, unfiltered information and most students lack the critical skills to penetrate this mass of undifferentiated material [5]. In teaching practice, if some students do not master the learning content that should be grasped, and they can even use the advantage of network to do some things which are not related to teaching objectives, this situation is difficult to control.

Secondly, simulation software is not perfect. Clark \& Mayer [3] put forward some problems which exist in some simulation software, for example, some software have limitation which can be used a university but maybe not suitable for another one. If a simulated environment is not accurate, it is harmful for practical teaching.

Although there are some disadvantages, for example, it is difficult to control during implementation and simulation software is not perfect, some scholars [6, 7, and 8] summarize many beneficial aspects in e-learning, as long as good use, it can promote students to study theoretical knowledge when they are involved in workintegrated learning:

It is conducive to independent study. Students' individual self-learning becomes a reality, and it is easy to make such acts as a good atmosphere on campus [6]. In fact, the learning environments based on e-learning, regardless of his students in the classroom, bedroom, practical site or library, students can find it very easy to exchange ideas around the students and teachers, and develop a good and positive learning atmosphere.

It is easy to combine popular classroom teaching with individual needs of learners. Classroom-based learning usually focuses on the teacher, and e-learning is based on student-centered, emphasizing self-learning. For selflearning ability of students, e-Learning will be the perfect complement to teaching.

It is easy for students to familiarize themselves with the E-learning environment. Long-term use of e-learning will help students adapt to a variety of learning needs in the future, and achieve a solid foundation for lifelong learning [9].

\section{The Study of Teaching Platform Based on E-learning}

Nowadays, there are a variety of e-learning platform which design for students in higher education or further education, but many platform designer just replicate a PowerPoint presentation and do not make a good elearning. In fact, one of the indicators of poor e-learning is the extent to which is a passive medium where learners are expected to interact only with the next button when they read through the text on screen [11]. It is boring, if a presentation just contains texts. So many designers use cartoon characters to make it interesting. People were intensely proud of their ability to create a virtual manager who chatted away to you. The problem with this was that learners found it patronizing. They found their managers were less on board with messages which could only be given using some kind of children's cartoon character from the early 90s and were therefore less likely to support their team members' use of these programs. One-way presentations usually require the 
learner to go through it in a pre-prescribed path using every unit in order. Hoyle [11] call this kind of e-learning 'edu-comms'. It is essentially a communications piece and one which requires people to act differently having been informed.

In the teaching practice of cooperative education, the students should have dual status, they not only accept the guidance of teachers in the school, but also a business intern, who receive instructors (or part-time teachers in the company) guidance. Different students also take part in different type of work in varied work place. The teaching platform for them can be designed to allocate the assignments according to their roles in the practice not just presentation. Students need more interactive in their on-line learning.

\section{A. The function of e-learning platform for teaching}

E-learning teaching includes one-way information transmission, interactive, video transmission, remote teaching and so on [5]. Firstly, students who are in work placement can propose their study requirements of appropriate course combining their specialty with their internship positions, and these are according to the students' needs and under the guidance of their instructors (or part-time teachers in the company). Secondly, according to student's learning requirements, teachers build curriculum packages for students to create a good learning environment and provide the necessary guidance and help. Teachers and students exchange the information through an e-learning teaching platform. Because this kind of teaching platform is used through computers, multimedia equipments, networking and communication equipments, it can provide students with an animating and interesting teaching platform. Comparing to the traditional teaching model, it can encourage students to learn to be more interested in it.

\section{B. E-learning and student-centered learning}

According to existing literature, one of the key factors in designing courses with a high level must be the development of a student-centered, rather than teacher-centered learning environment. Mason and Rennie [5] argued "Based on constructivists theories of learning, student-centered approaches to course design create an environment in which learners discover or work out for themselves an understanding of the subject or concept through critical analysis and reflection, often in conjunction with other learners." The teachers' role is like the foundation for constructive interaction and to negotiate with students to share their own ideas. The course designer needs to understand the strengths and weaknesses of available technologies and to know something about the background of the potential students [10].

\section{The structure of e-learning teaching platform}

An e-learning teaching platform is not just only to provide a simple exchange of information, but also create a special atmosphere to encourage students to participate in learning activities. By being different from traditional classroom teaching, in e-learning teaching environment, teachers and students are not only isolated in geography but are often asynchronous in time [9]. How can effective interaction between teachers and students be set up and among the students is the key. In order to ensure smooth interaction and access to resources between teachers and students, we need to use the Internet and modern means of communication to establish the teaching and management platform based on e-learning, and then systematically manage teaching resources, and design e-learning platform for teachers in teaching and students' work areas.

Teachers' work area provides teachers support services including video communication, chat rooms, whiteboard, prompt messages and courses. Video communication can realize one-to-one communication for online users via video and audio; chat rooms can realize real-time online chat ; whiteboard can be used that online users can see the information from other online users; prompt messages give information on homework and tutorial prompts; courses include bulletin boards, forums, tutorials, hand in papers, chat rooms, download, etc.

Students' work areas also have many functions to provide students support services, including personal information inquiry and statistics, students' educational management, personal learning tool, prompt message, courseware learning, teachers' tutorial download, hand in papers, discussion board and chat room. This kind of

Sponsors : $<$ Exploration and Practice on Work-integrated training Mode Cultivating in Higher Vocational Education of Computer Engineering >--2009 Teaching Reform Projects of Jiangxi Province

Project NO: JXJG-09-13-3 
platform will help the interaction between teachers and students. Under this type of environment, teachers are no longer the individuals of authoritative intervention but must have a certain degree of monitor method and create a situation which can encourage student play an initiative role in the exchange. Teachers also should guide the students in active learning. Figure 1 has been designed to show the basic elements in e-learning teaching environment.

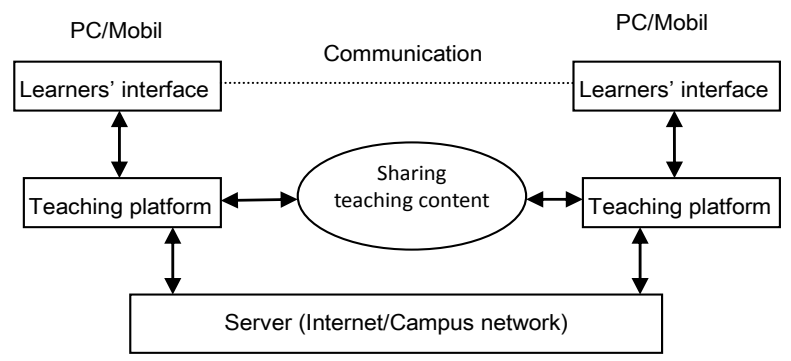

Fig. 1 The basic elements in e-learning teaching environment

\section{E-learning teaching process}

\section{A. E-learning teaching implementation stage}

In cooperative education, the implementation process of e-learning teaching is generally divided into the following four stages.

Stage 1: The phase of building problem. Full-time teachers set up practical course packages for students. The course package contains a series of problems related to. When students are in practice, they can select the appropriate status issues to learn in part-time according to their own internship positions under the guidance of teachers.

Stage 2: Completing the stage of experience. Full-time teachers determine the learning progress and assign tasks according to the problems and internship positions which students choose. Students use both self-learning and e-learning learning methods simultaneously under the guidance of part-time teachers in enterprise.

Stage 3: The stage of expression and communication. Teachers through the network and communications answer the questions and problems; students learn and submit online exercises through an e-learning platform.

Stage 4: The stage of evaluation. Full-time teachers use an e-learning platform for online assessment of students; part-time teachers assess students in the practice.

The four stages are not completely separate, but overlapping interaction and propulsion. Figure 2 has been designed to show E-learning teaching process. 


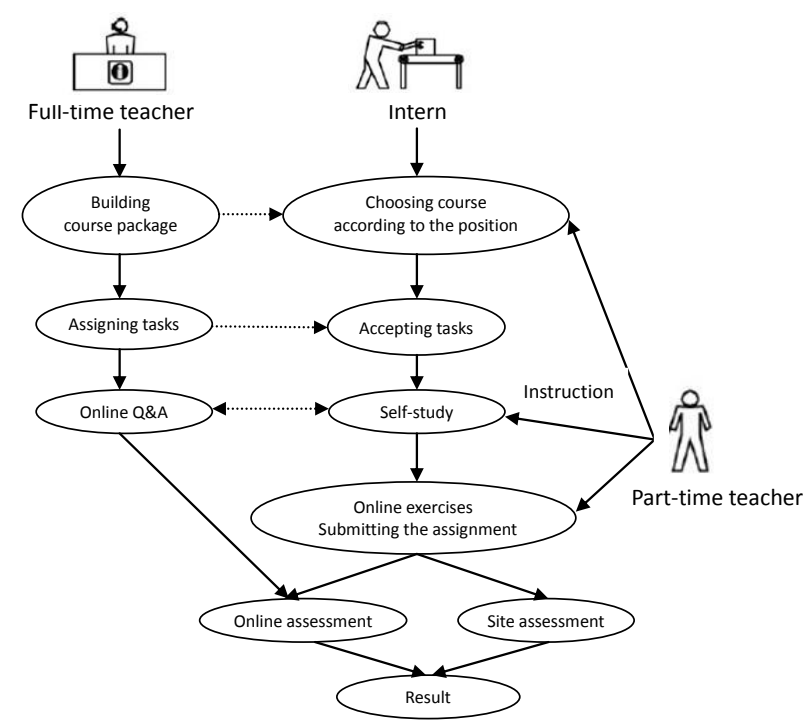

Fig. 2 E-learning teaching process

\section{B. E-learning teaching process}

1) Filtering the teaching content of course package.

Everyone who is concerned with effective training must, however, retain primary focus on the needs of the learner [4]. Cooperative vocational education should solve the problem of upgrading vocational students' professionalism, the accumulation of practical skills and capacity to adapt to the job. So it is not any problem can become a task for students' practice. When building curriculum package, teachers should pay attention to the following principles:

a) Reality related.

The challenges are selected should be related to students' internship positions. The best way is to find which of these urgent need to be addressed. These topics should help students put course content into practice in analyzing and solving problems. The knowledge learned can give students a deeper understanding which can be built on in future.

b) Diversity perspective of problem-based learning should be considered.

For example, Teachers should provide a number of cross-disciplinary problem so that students can do research from different perspectives. Teachers should also respect different backgrounds including their nationality, professional experience and hobbies to meet the student's individual development [6].

c) Problem operability.

Teachers should estimate students' strength before acting, and teachers should consider the possibility of completing topics from the subjective and objective conditions [7]. In other words, the problem should not be too large as if it is the beyond the students' capability, it will affect their enthusiasm and problems may remain unsolved. Furthermore, issues related to the content cannot be too abstract, or too difficult, as students may not be able to complete them.

\section{2) Confirming learning task}

Teacher-designed curriculum package is used in e-learning platform to students for discussing, reference and 
selection. Students seek advice from teachers on these issues, or discuss them with their peers. Finally, the students determine their own themes according to their internship positions, interests, strengths, etc. If teachers are not satisfied with the topics that students select or they have some specific ideas, they can submit them to teachers. After a full discussion between teachers and students, they can finally determine the learning task.

\section{3) Problem solution}

Learning tasks can be completed based on students' specific circumstances, such as independent study or forming study groups [10]. After the students determine their learning tasks, they can publish their own topics and discuss their progress on forum. They can also consider the situation of other students, and thus they can consider their own solution by looking at that of their peers. According to the consistency of topic or the rule of complemented capacity, the students can be combined into study groups. The number of people in such groups should not be too much, generally, 3 to 5 is appropriate. The teacher's role is not only to balance the number of such groups, but also ensure a variety of topics. After allocating the mission, $t$ study groups can explore their own issues through the modules, including the information provided by e-learning and real work placement. During the study period, group members or team members and teachers share learning progress, methods and content. When students encounter problems, teachers can help students solve problems together and provide them with appropriate help.

\section{4) Results and evaluation}

After some time of learning, each group exchanges their learning outcomes, evaluates and amends mutually through the e-learning platform. The teachers open up an evaluation section for each group, so that other team members can be involved in peer assessment. Finally, through the appropriate proportion, teachers give a clear result for each study group, which could contribute to their final work.

Work-Integrated teaching mode based on an e-learning platform is tailored designed for the teaching of information age. At present, the platform has been put into practical use for a semester. The experiments show that teachers can get feedback about students' working situation through their online reflection diaries. Students can also keep abreast of school information and use course packages which were developed by their teachers to continue studying theoretical knowledge. Students in task group work together to solve the tasks in course packets which were uploaded by their teachers. It will stimulate students' creative thinking skills. Through the teachers' evaluation and peer assessment, each group can get their learning results. The teaching platform is easy to use, functional and reasonable designed, and meets the demands of work-integrated teaching and learning.

\section{Conclusion}

E-learning changes the traditional learning style so that students from only studying among the classroom, library and laboratory to studying in work placement. Because of the combination of learning and working, learning efficiency and teaching quality are improved. However, e-learning also raise new issues, such as the construction of teaching platform and rich digital teaching content. These will greatly increase the workload of teachers which is clearly a disadvantage. Meanwhile, since video production, multimedia production, software development, platform maintenance, etc. require more manpower, the staffs associated with e-learning teaching support will also be greatly increased. Finally, while completing the construction of website, e-learning education needs more teachers who have good capability in information technology teaching to meet the new challenges.

\section{References}

[1] Chao-Tung Yang \& Hsin-Chuan Ho (2005). An e-Learning Platform Based on Grid Architecture. Joural of Information Science and Engeering 21, 911-928 
[2] Allan (2002) E-learning and teaching in library and information services. Facet Publishing.

[3] R. C. Clark \& R. E. Mayer (2007) E-learning and the science of instruction:

[4] M. Sloman (2001) The e-learning revolution: from propositions to action. Chartered Institute of Personnel and Development.

[5] R. Mason \& F. Rennie (2008) E-learning and social networking handbook. Routledge.

[6] Klaus P. Jantke, Steffen Lange, Gunter Grieser, Peter Grigoriev, Bernhard Thalheim, and Bernd Tschiedel. Work-integrated e-learning - the DaMiT approach. In 49. Internationales Wissenschaftliches Kolloquium, TU Ilmenau, 27.-30. September 2004.

[7] J.K. Seale (2006) E-learning and disability in higher education: accessibility research and practice.Routledge.

[8] K. P.Jantke and R.Knauf (2005). Didactic Design through Storyboarding: Standard Concepts for Standard Tools. First Intl. Workshop on Dissemination of E-Learning Systems and Applications (DELTA 2005). Proc. of ACM Press.

[9] Grundén, K. (2004) "A case study of work-integrated learning", Journal on Systemics, Cybernetics and Informatics, vol 2.

[10] A.G.Picciano(1998) Developing an asynchronous course model at a large, urban university. Journal of $\begin{array}{lllll}\text { Asynchronous } & \text { Learning } & \text { Networks, } & 2(1), & \end{array}$ http://www.aln.org/alnweb/journal/vol2_issue1/picciano.htm

[11] Relan \& Gillani, B (1997). Web-based instruction and the traditional classroom: Similarities and differences. In B. Kahn (Ed.), Web-based instruction. Englewood Cliffs, NJ: Educational Technology.

[12] Robin Hoyle (2010) What makes bad elearning? http://www.trainingzone.co.uk/topic/learningtechnologies/what-makes-bad-elearning-part-2/146118 